\title{
Embryonic stages in cerebellar afferent development
}

\author{
Maryam Rahimi-Balaei ${ }^{1,2}$, Pegah Afsharinezhad ${ }^{1}$, Karen Bailey ${ }^{1}$, Matthew Buchok', Behzad Yeganeh ${ }^{3}$ \\ and Hassan Marzban ${ }^{1,2^{*}}$
}

\begin{abstract}
The cerebellum is important for motor control, cognition, and language processing. Afferent and efferent fibers are major components of cerebellar circuitry and impairment of these circuits causes severe cerebellar malfunction, such as ataxia. The cerebellum receives information from two major afferent types - climbing fibers and mossy fibers. In addition, a third set of afferents project to the cerebellum as neuromodulatory fibers. The spatiotemporal pattern of early cerebellar afferents that enter the developing embryonic cerebellum is not fully understood. In this review, we will discuss the cerebellar architecture and connectivity specifically related to afferents during development in different species. We will also consider the order of afferent fiber arrival into the developing cerebellum to establish neural connectivity.
\end{abstract}

Keywords: Mossy fiber, Climbing fiber, Neuromodulatory fiber, Cerebellar primordium

\section{Introduction}

The cerebellum is responsible for coordinating movement and maintaining equilibrium, and it is also involved in behavioral, cognitive and emotional functions [1-4]. Proper cerebellar function depends on well-organized neuronal connections and the integration of afferent and efferent fibers throughout cerebellar circuitry [5]. The cerebellum can be divided into two longitudinal regions along the rostral to caudal axia, which are anatomically named the vermis and hemisphere. Mediolaterally, each of these regions is folded into lobes, lobules and folia. Traditionally, the cerebellum is divided into 3 lobes that are further subdivided into 10 lobules. Lobules I-X numbering is used for the lobules of the vermis and the corresponding lobules of the hemisphere are indicated with the prefix $\mathrm{H}$ (e.g. [6-8]). Recent studies suggest that the fundamental architecture of the cerebellum is organized into five transverse zones based on gene expression and afferent fiber termination; the anterior zone (AZ: lobules

\footnotetext{
* Correspondence: hassan.marzban@umanitoba.ca

'Department of Human Anatomy and Cell Science, College of Medicine, Faculty of Health Sciences, University of Manitoba, Rm129, BMSB, 745

Bannatyne Avenue, Winnipeg, Manitoba R3E 0J9, Canada

${ }^{2}$ College of Medicine, Faculty of Health Sciences, Manitoba Institute of Child Health (MICH), University of Manitoba, Winnipeg, Manitoba, Canada
} Full list of author information is available at the end of the article
$\mathrm{I}-\mathrm{V}$ in mice), the central zone (CZ: lobules VI-VII, which is further subdivided into anterior $(\mathrm{CZa})$ and posterior $(\mathrm{CZp})$ components $[9,10])$, the posterior zone (PZ: lobules VIII-dorsal lobule IX), and the nodular zone (NZ: ventral lobule IX and lobule X) (e.g. [11-18]). The boundaries of these zones do not align with the lobes and lobules, but do correspond to the pattern of afferent termination, and thus provides a more functionally relevant way of dividing the cerebellum.

The three-layered cerebellar cortex contains six main neuronal cell types: stellate and basket cells in the molecular layer, Purkinje cell somata in the Purkinje cell layer, and granule cells, Golgi cells, and unipolar brush cells in the granular layer. Neurons of the cerebellar nuclei are located close to the roof of the fourth ventricle deep within the cerebellar white matter. The cerebellar nuclei and the lateral vestibular nucleus constitute the sole output (efferent) of the cerebellum, and play a central role in cerebellar circuitry and function (e.g. [1, 19-22]).

The cerebellum is connected to the brainstem by three pairs of peduncles (superior, middle, and inferior), which are the pathways by which cerebellar afferents and efferents enter and exit [23, 24]. Cerebellar afferents can be grouped into two major types: mossy fibers and climbing fibers. Mossy fibers constitute the majority of afferent fibers in the adult cerebellum and arise from multiple 
sources. There are four main groups of mossy fibers that project to specific parts of the cerebellum: 1) the somatosensory projections (spinocerebellar and trigeminocerebellar fibers), which originate from the spinal cord and the trigeminal system (ganglion and nuclei) respectively, and project primarily to lobules I-VI and lobule VIII (e.g. [23, 25-27]); 2) vestibulocerebellar projections, which originate from the vestibular system (ganglion and nuclei) and terminate in ventral lobules IX and the flocculus with the adjacent ventral flocculonodular $[28,29]$; 3) reticulocerebellar projections, which originate from the lateral reticular nuclei, the paramedian reticular nucleus and the nucleus of Roller, and nucleus reticularis tegmenti pontis terminate throughout the cerebellum, but generally mirror the projections of the spino/trigeminocerebellar and vestibulocerebellar systems (e.g. [30-33]) pontocerebellar projections, which originate from the pontine nuclei and terminate throughout the cerebellum, especially in the vermis and hemispheres of lobules VI-VII (central zone), but not in the nodulus and flocculus [34-36]. The nucleus prepositus hypoglosi is also a source of a mossy fiber system that projects restricted regions of crura I and II as well as the caudal vermis and vestibulocerebellum [37]. Mossy fiber afferents communicate with cerebellar nuclei neurons and with Purkinje cells through granule cells/parallel fibers [24, 38-40]. Climbing fibers are exclusively derived from the inferior olivary complex and enter the contralateral cerebellum through the inferior cerebellar peduncle $[41,42]$. Climbing fibers directly synapse with the cerebellar nuclei and Purkinje cells (the sole output cells of the cerebellar cortex) [43-45]. In addition, a third set of afferents not categorized as mossy or climbing fibers exists, which terminate in all three layers of the cerebellar cortex and the cerebellar nuclei. Their functional role is neuromodulation and thus, they are categorized as neuromodulatory cerebellar afferents (i.e., serotonergic, noradrenergic, acetylcholinergic, dopaminergic, and histaminergic neuromodulatory afferents) (e.g. [1, 46-49]).

Extension and direction of early afferent fibers (axon pioneers) to their target neurons during development is controlled by genes and molecules, which mostly play a role in repulsion attraction (e.g. [50]). Several families of these proteins have been identified and among them four well-characterized families play an important role in axon guidance and development such as; Ephrin/Eph [50, 51], Semaphorins/ Neuropilins, [52, 53], Netrin $[54,55]$, and Robo/Slit [56, 57]. Molecules, such as integrins, fasciclin and neural cell adhesion molecules (NCAMs), are important in pioneer axon development by providing a substrate that promotes outgrowth of growth cones [58]. In addition, morphogens, initially characterized based on their effects on early patterning, are being increasingly implicated in axon guidance [50]. Morphogens found to be essential in cerebellar development include the Wnts family [59], Sonic hedgehog (Shh) [60, 61] and bone morphogenetic proteins (BMPs) [62]. These molecules from cell surfaces and intracellular signaling pathways provide cues that enable growing axons to terminate at their target cells. The Eph/Ephrin gene family has been indicated as a possible molecular pathway involved in regulating afferent patterning in both chick and mouse embryonic cerebella [63-65]. Engrailed-2 is important in development of cerebellum and regulates mossy fiber projections $[66,67]$. UNC-5, a Caenorhabditis elegans protein that is essential for dorsal guidance of pioneer axons is important in development of the rostral cerebellum [68]. It has also been suggested that axonal development in the cerebellum is regulated by WNT-7a signaling [69]. Furthermore, gene mapping studies have shown that precerebellar nuclei including inferior olivary nuclei neurons likely originate from an area expressing Ptf1a, Oli3 and Wnt1 (e.g. [70]). Brn3 expression has been shown to be necessary for inferior olivary nuclei development [71]. Gene expression appears to be conserved across vertebrates as the inferior olivary nuclei of zebrafish also express ptf1a and brn3a [72]. It is known that the cerebellum and inferior olive express neurotrophins and their receptors that are involved in climbing fiber development [73]. It is also known that some genes are expressed differently in subsets of mossy fibers (e.g. somatostatin) and climbing fibers (e.g. corticotropin releasing factor) [74]. However, the regulatory roles of these genes and proteins in cerebellar afferent projections are poorly understood and will be interesting to investigate further to understand cerebellar circuit formation during cerebellar development.

The basic organization of afferent and efferent cerebellar connections appears to be conserved throughout evolution [75]. While there is much information regarding sources, pathways, terminations, and functions of afferents in the adult cerebellum, little attention has been paid to the subject during embryonic development. The order of afferent fiber arrival during cerebellar development is likely to be important in setting up the principal cerebellar circuits, but this is poorly understood. The basic spatiotemporal pattern of cerebellar afferents appears to be common between mammals, avians, reptiles, amphibians, and fish (e.g. [76, 77]). Therefore, in this review, we integrate information from different species in an attempt to resolve the order of afferent fiber arrival into the developing cerebellum.

\section{Review}

\section{Development of cerebellar afferents} Mossy fibers

Mossy fiber projections probably play a critical role in establishing and organizing cerebellar circuitry during 
early embryonic development. Conventionally, it is believed that mossy fibers enter the early embryonic cerebellum and target the Purkinje cells. However, it has been demonstrated that mossy fiber contacts with Purkinje cells are temporary and transient. Postnatally, as the granular layer matures, mossy fibers displace from Purkinje cells and synapse with their adult targets, the granule cell dendrites (e.g., [14, 77-81]). This multistage process of mossy fiber relay on timing and order of arrival during cerebellar development could be required for proper circuit formation and/or for afferents to pattern the target tissue.

\section{Somatosensory pathway}

Somatosensory input is carried into the cerebellum via spinocerebellar and trigeminocerebellar tracts.

\section{Spinocerebellar afferents}

The spinocerebellar afferent system is comprised of the dorsal spinocerebellar, ventral spinocerebellar, cuneocerebellar, rostral spinocerebellar tracts and from the central cervical nucleus which collectively convey proprioceptive information to the cerebellum. However, dorsal spinocerebellar tract component from lamina $\mathrm{V}$ and cuneocerebellar component from the internal cuneate nucleus transmits exteroceptive information to the cerebellum. The spinocerebellar afferents originate from diverse laminae of the spinal cord and can be classified into crossed and uncrossed tracts according to the cell origin and fiber course [82]. The cerebellum receives proprioceptive information from the hind limbs through the dorsal spinocerebellar tract (uncrossed) and the ventral spinocerebellar tract (crossed) [82, 83]. The dorsal spinocerebellar tract originates from the dorsal horn (mainly dorsal thoracic nucleus that is also known as Clarke's column) and provides a major mossy fiber input to the spinocerebellum, which plays a significant role in the control of posture and locomotion $[84,85]$. The input conveyed by the ventral spinocerebellar tract originates from neurons of the dorsal and ventral horn and it monitors activity of spinal interneuronal networks $[82,86,87]$. The cuneocerebellar and rostral spinocerebellar tracts are the upper limb equivalents of the dorsal and ventral spinocerebellar tracts, respectively. The sources of these tracts are well known: the cuneocerebellar tract originates from the external and internal cuneate nucleus and the gracile nucleus in the medulla oblongata and the rostral spinocerebellar tract originates from the cervical spinal cord. The termination of all spino- and cuneocerebellar tracts is in bilateral, alternating symmetrically disposed longitudinal aggregates of mossy fiber terminals. The spinocerebellar afferents project to the cerebellum through the inferior cerebellar peduncle (non-crossed) and the superior cerebellar peduncle (crossed), and terminate in the anterior zone (lobules I-V) and posterior zone (lobules VIII-IXd) $[28,88]$.

Clinically, the spinocerebellar system is involved in a heterogeneous group of disorders classified collectively as spinocerebellar ataxia [89]. Spinocerebellar ataxia is a neurodevelopmental and neurodegenerative disease characterized by progressive incoordination of movement and degeneration of the cerebellar cortex and spinocerebellar pathways $[89,90]$. It is believed that the cerebellar circuit organization, which is established during early cerebellar development, may be altered in ataxia (e.g. [91]).

\section{Development of the spinocerebellar afferents}

Spinocerebellar mossy fiber projections to the cerebellum during prenatal development have been studied in mice using in vitro tract tracing techniques (e.g. [22, 92]). Results of these studies have shown that at embryonic day 12/13 (E12/13), neuronal sources of spinocerebellar mossy fibers from the caudal cervical spinal cord are present, but there are no projections to the cerebellum. At approximately E13/14, spinocerebellar projected fibers have been shown to be present in the rostrolateral portions of the cerebellum adjacent to the isthmus region. Spinocerebellar fibers progress farther into the cerebellum and the number of crossed fibers increases as aging occurs [22]. In rats, tract-tracing methods have shown that spinocerebellar fibers project to the cerebellum in two successive groups: the first group is present in the cerebellum perinatally and the second group reaches the cerebellum by postnatal day 3 (P3) and targets the vermis of the anterior lobe and pyramis [93]. However, this timing was revised by Ashwell and Zhang, who showed that spinocerebellar fibers may be present in the developing rat cerebellum at around E15 $[92,94]$. The external cuneate neurons are generated from the caudal rhombic lip between E13 and E15 in mice and may enter into the cerebellum during E13-E15 and thereafter $[7,95]$. In the rat, cuneocerebellar fibers arrive in the developing cerebellum by E16/17 ipsilaterally via the inferior cerebellar peduncle [6].

In the chicken, spinocerebellar projections have been studied by injecting WGA-HRP into the spinal cord of embryos at different stages of development. These studies showed that spinocerebellar fibers entered the cerebellum at around the 7th incubation day [96]. In the African clawed frog, Xenopus laevis, spinocerebellar afferents were studied using HRP tracer techniques. At approximately stage 50 , before the formation of the limbs, the ventral spinocerebellar projections appeared to be present in the cerebellum prior to entry of the dorsal spinocerebellar tract [97]. Although primary spinocerebellar projections from spinal ganglion cells to the cerebellum have been demonstrated in the adult frog $[98,99]$, they were not detectable during development [97]. Tract tracing methods 
have also been used to study spinocerebellar projections in reptiles including turtles (Pseudemys scripta elegans and Testudo hermanni), lizards (Varanus exanthematicus), and snakes (Python regius). The basic pattern of cerebellar afferent projections appears to resemble that of other vertebrates. However, it has been suggested that there is no column of Clarke or central cervical nucleus in the reptilian spinal cord [99]. To our knowledge, no developmental studies have investigated spinocerebellar projections in reptiles. In the lesser spotted dogfish (Scyliorhinus), spinocerebellar afferents were shown to project to the developing cerebellum at around stage 32 (equivalent to around E14.5 in the mouse) $[100,101]$.

In summary, spinocerebellar fibers invade the developing cerebellum at around E13/14 in the mouse (e.g. [22, 92]), E15 in the rat [94], HH33 (Hamburger-Hamilton stages 33) in the chicken (around the 7th incubation day; [96]), stage 50 in Xenopus laevis [97], and at stage 32 in the dogfish [101, 102] (Tables 1 and 2).

\section{Trigeminocerebellar afferents}

The trigeminal system (trigeminal nerves, ganglion, and nuclei) is the largest cranial nerve, which has both sensory and motor components [103]. Peripherally, the trigeminal nerve is comprised of three branches: ophthalmic (V1, sensory), maxillary (V2, sensory), and mandibular (V3, sensory and motor), which converge together on the trigeminal ganglion. From the trigeminal ganglion, a single large sensory root enters the brain stem at the level of the pons and terminates at the complex trigeminal nuclei, which consist of the spinal trigeminal nucleus, main (principal) trigeminal nucleus, and mesencephalic trigeminal nucleus. The motor component is derived from the basal plate of the embryonic pons, while the sensory component originates from the alar plate and the neural crest (e.g. [104]).
The trigeminal nerve carries temperature, pain and tactile information from the skin, jaws and teeth. In addition, it carries proprioceptive input primarily from the muscles of mastication to the mesencephalic trigeminal nucleus, which projects to higher centers to coordinate jaw movement in activities such as suckling, mastication, biting and speech (e.g. [105]). In adult rats, the mesencephalic and interpolaris trigeminal nuclei have direct projections to the cerebellum $[106,107]$. There are also primary trigeminal afferent projections from the ganglion (probably from the mandibular branch) to the cerebellum of adult rats [108]. The primary trigeminocerebellar projections (originating from the trigeminal ganglion) run through the superior peduncle, whereas secondary trigeminocerebellar projections (originating from the trigeminal nuclei) run through the inferior peduncle, and both terminate in the same target areas in the cerebellum [26, 109].

In the cerebellum, the mesencephalic tract nucleus projects to the anterior lobe, the simple lobule (HVI), lobules VI, VIII, and the dorsal paraflocculus (e.g. mice [27], rats [109], and sheep [110]). The ventral group of the main (principal) and spinal tract nuclei project to all lobules in the vermis and hemispheres, whereas the dorsal parts of these nuclei have a more restricted projection field including the vermis of the lobules VI, VII, and IX and corresponding hemispheres [110]. In the rat, the trigeminal nucleus oralis projects to ipsilateral orofacial portions of four major tactile areas (crura I and II, the paramedian lobule, and the uvula) of the cerebellar cortex $[111,112]$. Retrograde tracing has shown that most of the spinal trigeminal nuclei project to the paramedian lobule in the tree shrew (Tupaia glis), but the principal and mesencephalic trigeminal nuclei do not [113]. Trigeminocerebellar afferents have been demonstrated in Xenopus laevis [114]. In mallards, the trigeminocerebellar afferents terminate predominantly in lobules V, VI and VII, and possibly in

Table 1 Timing of cerebellar afferent fiber arrival in different species during the embryonic period

\begin{tabular}{|c|c|c|c|c|c|c|}
\hline Afferent fiber & Mouse & Rat & Chicken & Xenopus & Reptile & Fish $^{a}$ \\
\hline Spinocerebellar a & $\mathrm{E} 13 / 14$ & E15 & HH33/E7 & Stage 50 & $\mathrm{n} / \mathrm{a}$ & Stage 32 \\
\hline Trigeminocerebellar a & $\mathrm{n} / \mathrm{a}$ & $\mathrm{E} 22 / \mathrm{PO}$ & $\mathrm{n} / \mathrm{a}$ & Stage 48 & $\mathrm{n} / \mathrm{a}$ & Stage 32 \\
\hline Vestibulocerebellar a & E11-13 & $13-14 / 15$ & $\mathrm{n} / \mathrm{a}$ & Stage 48 & $\mathrm{n} / \mathrm{a}$ & $\mathrm{n} / \mathrm{a}$ \\
\hline Reticulocerebellar a & $\mathrm{E} 13 / 14$ & $\mathrm{E} 16 / 17$ & $\mathrm{n} / \mathrm{a}$ & Stage 48 & $\mathrm{n} / \mathrm{a}$ & Stage 32 \\
\hline Pontocerebellar a & E16 & perinatal & $\mathrm{n} / \mathrm{a}$ & $\mathrm{n} / \mathrm{a}$ & $\mathrm{n} / \mathrm{a}$ & $\mathrm{n} / \mathrm{a}$ \\
\hline Olivocerebellar a & E14/15 & E17 & E9 & $\mathrm{n} / \mathrm{a}$ & $\mathrm{n} / \mathrm{a}$ & Stage 32 \\
\hline Serotonergic cerebellar a & postnatal & postnatal & $\mathrm{n} / \mathrm{a}$ & Stage 56 & $\mathrm{n} / \mathrm{a}$ & $\mathrm{n} / \mathrm{a}$ \\
\hline Noadrenergic cerebellar a & E14 & E17 & $\mathrm{n} / \mathrm{a}$ & $\mathrm{n} / \mathrm{a}$ & $\mathrm{n} / \mathrm{a}$ & $\mathrm{n} / \mathrm{a}$ \\
\hline Cholinergic cerebellar a & $\mathrm{n} / \mathrm{a}$ & $\mathrm{n} / \mathrm{a}$ & $\mathrm{n} / \mathrm{a}$ & $\mathrm{n} / \mathrm{a}$ & $\mathrm{n} / \mathrm{a}$ & $\mathrm{n} / \mathrm{a}$ \\
\hline Dopaminergic cerebellar a & $\mathrm{n} / \mathrm{a}$ & $\mathrm{n} / \mathrm{a}$ & $\mathrm{n} / \mathrm{a}$ & $\mathrm{n} / \mathrm{a}$ & $\mathrm{n} / \mathrm{a}$ & $\mathrm{n} / \mathrm{a}$ \\
\hline Histaminergic cerebellar a & $\mathrm{n} / \mathrm{a}$ & $\mathrm{n} / \mathrm{a}$ & $\mathrm{n} / \mathrm{a}$ & $\mathrm{n} / \mathrm{a}$ & $\mathrm{n} / \mathrm{a}$ & $\mathrm{n} / \mathrm{a}$ \\
\hline
\end{tabular}

Note: $a$, afferent fiber

The " $\mathrm{n} / \mathrm{a}$ " means that there is no data available for afferents projection to the cerebellum during embryonic development in these species

${ }^{a}$ This is the only stage that has been studied; therefore everything arrives at stage 32 
Table 2 Timing of cerebellar afferent fiber arrival in different species during embryonic and postnatal stages

\begin{tabular}{|c|c|c|c|c|c|c|c|c|c|c|c|}
\hline \multirow{2}{*}{$\begin{array}{l}\text { Afferent fiber } \\
\text { Days }\end{array}$} & \multicolumn{9}{|c|}{ Embryonic } & \multicolumn{2}{|c|}{ postnatal } \\
\hline & 2 & 4 & 6 & 8 & 10 & 12 & 14 & 16 & 18 & $0 / 2$ & adult \\
\hline Spinocerebellar a & & & & $>$ & & & 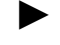 & $>$ & $>$ & & \\
\hline Trigeminocerebellar a & & & & $>$ & & & & & & $>$ & \\
\hline Vestibulocerebellar a & & & & $>$ & & $>$ & D & & & & \\
\hline Reticulocerebellar a & & & & $>$ & & & $>$ & $>$ & & & \\
\hline Pontocerebellar a & & & & & & & & $>$ & & D & \\
\hline Olivocerebellar a & & & & & $>$ & & $>$ & & $>$ & & \\
\hline Serotonergic cerebellar a & & & & & & & & & & & $>$ \\
\hline Noradrenergic cerebellar a & & & & & & & $>$ & & $>$ & & \\
\hline Cholinergic cerebellar a & & & & & & & & & & & \\
\hline Dopaminergic cerebellar a & & & & & & & & & & & \\
\hline Histaminergic cerebellar a & & & & & & & & & & & \\
\hline
\end{tabular}

lobule IV, and are ipsilateral except for the vermal area [115]. The secondary trigeminocerebellar projections have been demonstrated in mammals (e.g. [116]), birds [117], reptiles [100], and amphibians [114].

\section{Development of the trigeminocerebellar afferents}

In the central nervous system, mesencephalic neural crest cells emerge and start migrating at the 4- to 7somite stage in mice, some of which give rise to the primary sensory neurons that form the mesencephalic trigeminal nucleus [104]. At E8.5, by the 10-somite stage, the first group of neurons can be identified in the rostral part of the mesencephalon [104]. This is the earliest neuronal development that has been detected in the central nervous system; this is in contrast to previous information, which indicated that neurons first differentiated in the mouse central nervous system by E9-E10 [104]. It has been demonstrated that the cells of the mesencephalic trigeminal nucleus are born before E11 in rats [118], and as early as E8 in mice [104]. Although formation of this nucleus takes place during early neural tube development, Ashwell and Zhang have suggested that the trigeminocerebellar afferents project to the cerebellum around E22 in rat [94].

Information regarding the development of trigeminal projections in the avian cerebellum is limited. In reptiles, the presence of trigeminocerebellar projections has been demonstrated [100], but not studied during development. In amphibians (Xenopus laevis), the secondary trigeminocerebellar projection (from the descending nucleus of the trigeminal nerve) has been shown in the cerebellum at approximately stage 48 [97]. In addition, trigeminocerebellar fibers can be observed in the cerebellum at stage 32 in the dogfish [102] (Tables 1 and 2). Thus, the trigeminal system components seem to be among the earliest neurons and fibers to develop in the vicinity of the cerebellar primordium. However, the lack of clarity in the timing of the developing trigeminocerebellar projections requires further research.

\section{Vestibulocerebellar afferents}

The vestibulocerebellar system, which is important for maintaining balance and equilibrium, provides sensory input to the cerebellum [119]. The vestibular nucleus includes four subnuclei: superior, inferior, medial, and lateral [119]. The lateral vestibular nucleus does not receive vestibular root fibers, but Purkinje cell axons from the $\mathrm{B}$ zone (the lateral part of the vermis), therefore, it is a cerebellar rather than a vestibular nucleus [28]. Projections from the vestibular system to the cerebellum are comprised of two components: primary vestibular mossy fiber afferents (i.e. originate from the vestibular ganglion) and secondary vestibular mossy fiber afferents (i.e. originate from the vestibular nuclei) [120]. Vestibular nerve projections to the cerebellum are primarily limited to the nodulus, uvula, and flocculus [120, 121]. Additionally, in bottom deep fissures (basal part of the lobules), lobules I and II, where they are distributed in parallel longitudinal aggregates [122], the flocculus does not receive primary vestibular mossy fibers [123]. The "vestibular commissure" of Larsell would form the basis of the flocculonodular lobe [124]. Primary and secondary vestibulocerebellar afferents have been shown in amphibians $[125,126]$, reptiles $[100,127]$, birds [128] and mammals (e.g. $[116,129-131])$.

\section{Development of vestibulocerebellar afferents}

It is suggested that vestibular ganglion neurons are born on E10-E14 in mice [131], and E11-E13 in rats [132]. Vestibular nuclei projection neurons are born in 
the neuroepithelium lining the fourth ventricle between E12 and E14 in the rat in the following order: the lateral (approximately E12), superior (approximately E13), inferior (approximately E13-14), and medial vestibular nucleus (approximately E13-14) [132, 133]. Historically, the classical observation of Tello and Ramon Y Cajal (1909) suggested that vestibular fibers were the first afferents to reach the cerebellum at six days prenatal in the mouse. However, the timing was slightly revised some years later, with vestibular axons from the vestibular ganglia being the first afferents to enter the cerebellum at E13-14/15 in the rat and E11-12/13 in mice [94, 133, 134]. From E15, collateral branches from primary vestibulocerebellar afferents form contacts with the developing vestibular nuclei within the subventricular zone [134].

Vestibular nuclei are generated at around E2 in chickens [135]. However, to date there are no data for avian vestibulocerebellar fiber development. Developmental studies are currently lacking on reptilian vestibulocerebellar projections, but in amphibians (Xenopus laevis), it has been demonstrated that vestibulocerebellar projections, which mainly arise bilaterally in the nucleus vestibularis caudalis, appear at around stage 48 [97] (Tables 1 and 2). Although the vestibulocerebellar projections are suggested to be the earliest afferents to invade the cerebellar primordium, further studies using a greater range of experimental approaches are required to confirm this important and fundamental process.

\section{Reticulocerebellar afferents}

A mixture of neurons and nerve fibers located in the brainstem make up a poorly defined group of nuclei collectively referred to as the reticular formation. The reticular formation is a primitive neuronal network upon which a more morphologically organized mass of neurons have developed during evolution [135, 136]. The reticular formation can be divided into three bilateral longitudinal columns based on both structure and function: median (raphe nuclei), medial, and lateral nuclei [136]. The lateral reticular nucleus can be further divided into three subnuclei (parvocellular, magnocellular and subtrigeminal) that project to the cerebellum. The caudal and ventral part of the lateral reticular nucleus projects bilaterally, mainly to the vermis, its rostral and dorsal part, that receives the "ipsilateral forelimb tract" and a collateral projection of the rubrospinal tract projects to the ipsilateral hemisphere [137]. The paramedian pontine reticular nucleus projects bilaterally to the cerebellar lobules VI, VII and the crura I and II that symmetry about the medline [32]. The parvocellular portion and adjacent magnocellular portion project primarily to the vermis, the remaining magnocellular subnucleus projects to the hemispheres, and the subtrigeminal subnucleus projects to the flocculonodular lobe. Neurons of the reticular formation project to the cerebellar cortex and cerebellar nuclei through the superior/middle/inferior cerebellar peduncles [138]. Reticular formation projections, which are aligned with the cerebellar architecture, carry out functions such as orofacial behaviour, including eye blink reflexes $[39,138]$.

\section{Development of reticulocerebellar afferents}

In the rat, the reticulocerebellar nucleus is not identifiable until birth when the axons of these neurons reach the cerebellum, even though reticular nucleus neurons are born on E12/13 [30]. Other studies have suggested that axons from the lateral reticular nuclei begin arriving in the developing cerebellum by E16/17 in rat (equivalent to E13/14 in mouse; [7]) via the inferior cerebellar peduncle [139]. At present, detail regarding the reticulocerebellar projections in the avian cerebellum is lacking (e.g. [96]). In reptiles, projections to the cerebellum were demonstrated from the reticular formation [100], but developmental studies in this system are currently required. Reticulocerebellar connections have been demonstrated experimentally at stage 48 in Xenopus laevis, [97]. In the dogfish, reticulocerebellar neurons are observed at stage 32 from the reticular formation of the mesencephalon and rhombencephalon [101, 102] (Tables 1 and 2).

The reticular formation is a complicated organization of nuclei that is involved in both sensory and motor pathways, and is generally one of the earliest nuclei to grow ontogenetically and phylogenetically. It seems that the reticulocerebellar projections are established early in development as a fundamental requirement to establish the basic functional circuitry of this pathway.

\section{Pontocerebellar afferents}

The pontine nuclei, located at the basilar portions of the pons (basilar pontine nuclei), receive most of their input from the cerebral cortex [140]. The majority of mossy fibres innervating the hemispheres originate from the pontine nuclei [138]. All pontocerebellar fibers end as mossy fibers in the cerebellar nuclei and cortex [141, 142]. The nucleus reticularis tegmenti pontis project to the cerebellar nuclei (pronounced in lateral and posterior interposed nuclei), the paraflocculus and crus II of the ansiform lobule [143]. The size of the pontine nuclei increases in parallel with the size of the associated cerebral cortex, reaching peak development in humans [136].

\section{Development of pontocerebellar afferents}

Pontine neurons arise from the lower rhombic lip around E14 to E17 and tangentially migrate to the ventral pons in the rat. At E16.5, migrating pontine neurons are present in the pontine nuclei with their axons laterally projecting towards the developing cerebellum [95]. These axons cross the midline and enter the cerebellum through the 
middle peduncle [144]. The neurons of the pontine nucleus are generated from the rhombic lip at E16 in mice [145], while in the rat, pontocerebellar nuclei are first labelled at birth [92]. It has been suggested that pontine mossy fibers enter the cerebellum perinatally in rat $[92,146]$. The pontocerebellar projections are found in birds and mammals [33, 128, 145-148], but projections from the primordial pontine nuclei to the cerebellum in reptiles and amphibians have not been demonstrated [100] (Tables 1 and 2).

\section{Climbing fibers}

Climbing fibers are the second major type of cerebellar afferents. Unlike mossy fibers, which originate from numerous sites in the nervous system, climbing fibers originate exclusively from the inferior olivary nucleus (e.g. [41, 149-151]). The inferior olivary nucleus can be subdivided into three major subnuclei: the principal olivary nucleus, which projects mainly to the cerebellar hemisphere, the dorsal accessory olivary nucleus, which projects to the vermis and hemispheres, and the medial accessory olivary nucleus, which projects to the vermis and paravermis in the rat [152]. Climbing fibers relay information to the cerebellum from several regions, such as the cerebral cortex, thalamus, red nucleus, reticular formation, trigeminal nuclei, and spinal cord. It is evident that inferior olivary neurons are necessary for proper cerebellar function, possibly in motor learning [153] and in motor timing [154]. The inferior olivary nucleus is a common feature of amphibians, reptiles, birds and mammals. Inferior olivary nucleus projections have been demonstrated experimentally in the frog $[155,156]$, and termination of these afferents in a longitudinal pattern has been demonstrated in the avian cerebellum [157]. The olivocerebellar circuit is essential for normal cerebellar function [158].

\section{Development of olivocerebellar afferents}

Several studies support that inferior olivary neurons originate from the caudal region of the rhombic lip, r6-8 (reviewed in [70]). Gene mapping studies have shown that IO neurons likely originate from an area expressing Ptfla, Oli3 and low levels of Wnt1 (reviewed in [70, 159]. Brn3 expression has been shown to be necessary for ION development [71]. Post-mitotic inferior olivary cells in the caudal hindbrain migrate circumferentially toward the ventral floor plate of the medulla where the mature inferior olivary nuclei will form $[139,160]$. Inferior olivary neurons originate at E10-11 in mice [70], E12-14 in rats [160], and E3-5 in chicks [161].

Axons of inferior olivary neurons begin migration before the cell bodies, such that the axons reach the cerebellum around the same time that the cell bodies settle in the ventral floor plate [162]. Organization of the inferior olivary subnuclei is clear by E10 in chicks [159] and E18/19 in rats [42, 139]. Olivocerebellar axons cross the midline and enter the contralateral cerebellum through the inferior cerebellar peduncle [42]. These axons reach the cerebellum around E14/15 in mice [163], E17 in rats [7, 164], and E9 in chicks [165]. Within the cerebellum, inferior olivary axons give off thick and thin branches. The thick branches form the climbing fibers, which terminate in the cerebellar cortex and synapse directly with Purkinje cells [42]. Immature climbing fibers have been shown to occur in the Purkinje cell region as early as P0 in mice $[9,166]$, and synapses have been found to occur as early as E19 in rats [167]. Early in postnatal development, each Purkinje cell is innervated by multiple climbing fibers. In rats, this occurs as early as P3 and peaks at P5, with an average of 3.5 climbing fibers per Purkinje cell $[168,169]$. Climbing fiber innervation is subsequently reduced leaving a single strong excitatory synapse [163]. Mono-innervation occurs by P15 in rats [169]. In mice, this process is longer, ending around the third postnatal week, with defined early and late stages $[151,170]$. The thin branches of the inferior olivary neurons terminate on the cerebellar nuclei [171]. In the North American opossum (Didelphis marsupialis virginiana), olivary axons reach the developing cerebellum at approximately postnatal day 4 [172].

From an evolutionary perspective, the lamprey, an ancient jawless fish/agnathan, possesses a region comparable to the cerebellum [173]. The presence of the inferior olivary nuclei in agnathans has not been demonstrated; however, the presence of the inferior olivary nuclei has been demonstrated in jawed fishes/gnathostomes (e.g. teleosts [72] and chondrichthyans [101, 102]). The inferior olivary nuclei in fish are considered to be homologous to the medial accessory olivary nucleus of mammals [174]. In the dogfish (chondrichthyan), the olivocerebellar projections develop after spinocerebellar projections [101, 102], similar to birds and mammals. These projections are first obvious during intermediate stage 32, when the first climbing fibers reach the cortex [101, 102]. In dogfish, Purkinje cells have matured by stage 32 [175], unlike mammalian development in which climbing fibers enter the cerebellum before Purkinje cells have matured. In zebrafish (teleost), the inferior olivary nucleus can be distinguished at 4 days post-fertilization in the ventromedial region of the posterior hindbrain, and climbing fibers have been shown to innervate Purkinje cells at 5 days post fertilization [72]. The development and organization of the olivocerebellar system appears to be conserved throughout vertebrates (e.g. [76, 175]). Overall, the arrival of inferior olivary projections to the cerebellum appears to happen at roughly equivalent developmental stages in fish, birds, and rodents (Tables 1 and 2). 


\section{Neuromodulatory afferents}

In addition to mossy fibers and climbing fibers, other cerebellar afferent pathways have also been discovered. These afferents originate from subnuclei of the reticular formation and are traditionally called neuromodulatory cerebellar afferents. They project to the cerebellum through the superior, middle, and inferior peduncles and in general terminate in all three layers of the cerebellar cortex. The neuromodulatory cerebellar afferents influence cerebellar circuitry in various ways and can be categorized into 5 groups based on the chemical messengers used for communication: serotonergic, noradrenergic, acetylcholinergic, dopaminergic, and histaminergic neuromodulatory afferents (e.g. [46-49]). In addition to their largely unknown function, the distribution and development of these afferents projection to the cerebellum is poorly understood.

\section{Cerebellar serotonergic afferents}

The serotonergic fibers are the largest modulatory afferent fibers to the cerebellum [49]. A combination of retrograde transport studies and serotonin immunohistochemistry has shown that serotonergic cerebellar fibers arise from a few of the reticular formation subnuclei: the nucleus reticularis gigantocellularis, the nucleus reticularis paragigantocelularis, and also from the pontine reticular formation in the nucleus reticularis pontis oralis [176]. In rats, serotoninergic fibers project to all parts of the cerebellar cortex. However, the distribution of fibers across the cerebellum is not uniform, with different densities projecting to the granule cell and molecular layer and to different lobules. The fibers also terminate in the Purkinje cell layer. The distribution is found to be thickest in lobules VIII-X of the vermis. A dense uniform plexus of serotonergic cerebellar fiber projections is present in the cerebellar nuclei of the cat cerebellum $[49,176,177]$. It seems that serotonergic fibers have modulatory effects on Purkinje cells and cerebellar nuclei $[178,179]$.

From a clinical point of view, the serotonergic abnormalities in the cerebellum may be involved in patients with developmental neuropsychiatric disorders such as autism and attention deficit/hyperactivity disorder (ADHD) $[180,181]$. Serotonin may disturb behavioral responses that are associated with cerebellar timing signals, such as the eye-blink reflex $[49,182]$.

\section{Development of cerebellar serotonergic afferents}

The expression of the serotonergic phenotype begins at E12 just caudal to the mesencephalic flexure, in rostral raphe nuclei [183, 184]. It is suggested that serotonergic projections to the cerebellum develop during the postnatal period [185], which coincides with the perinatal development of the cerebellar cortex. It has been shown that serotonergic fibers are present in the chicken [186], the opossum [172], and at stage 56 in the cerebellum of Xenopus (which may have originated from inferior raphe nucleus) [187] (Tables 1 and 2).

\section{Cerebellar noradrenergic afferents}

Noradrenergic afferents are the second largest modulatory input to the cerebellum [46] and originate from the locus coeruleus [188], a system that supplies noradrenaline (norepinephrine) throughout the central nervous system. The locus coeruleus is located in the pons, which is involved in physiological functions such as arousal, sleep/ wake cycles, nociception, anxiety, stress, learning and memory [189, 190]. Noradrenergic fibers project to all parts of the cerebellar cortex and are found around Purkinje cell dendrites, glomeruli, granule cell dendrites, and cerebellar nuclei [116]. The significance of noradrenergic cerebellar projections is suggested to be correlated with learning [191].

\section{Development of cerebellar noradrenergic afferents}

It is suggested that the locus coeruleus neurons are among the first central nervous system neurons to arise during ontogeny. In mice, these neurons originate from dorsal $\mathrm{r} 1$ between E10.5 to E12.5, and their axons may reach the cerebellum by E14 [192]. They establish axonal connections to their target areas while migrating into their nuclear area in 4th ventricle at around E17 in the rat (Tables 1 and 2). Noradrenergic axons are demonstrable in the developing cerebellum for the first time at E17 and the peak of innervation is reached at P10 [193]. This hyper-innervation is transitory and declines to adult values at around P20 [193].

\section{Cerebellar cholinergic afferents}

Cholinergic input to the cerebellum is thinly dispersed, creating a diffuse plexus of beaded fibers in the cerebellar cortex and cerebellar nuclei [194-196]. It has been proved that a subset of vestibular projections to the cerebellar cortex are cholinergic [196]. However, the reticular formation is the principal source of cholinergic cerebellar afferents [48]. In the rat cerebellum, cholinergic fibers originate in the pedunculopontine tegmental nucleus, the lateral paragigantocellular nucleus, and, to a lesser extent in various raphe nuclei [48]. Cholinergic afferents terminate in the granule cell layer and molecular layer of the cerebellum in rat, rabbit, and cat [194]. The cholinergic fibers in the cerebellar nuclei form a moderately dense network, and could, in principle, have a significant effect on neuronal activity [48].

\section{Development of cerebellar cholinergic afferents}

Using specific binding sites for $\left[{ }^{3} \mathrm{H}\right]$ quinuclidinyl benzylate, Mallol et al. suggested that cholinergic fibers are 
present at a low level in the cerebellum at birth [197]. However, there is limited information regarding cholinergic cerebellar afferents during development.

\section{Cerebellar dopaminergic afferents}

There are sparse dopaminergic projections to the cerebellar cortex and nuclei, which appear to originate mostly from the ventral tegmental area [198]. It has been demonstrated that most dopamine receptor proteins are present in Purkinje cells [199]. Dopamine can influence plasticity in Purkinje cells [46].

\section{Development of cerebellar dopaminergic afferents}

Dopaminergic neurons are born at approximately E10E14 in mice (E12-E16 in rats) from the ventral midbrain/mesencephalon floor plate [200]. However, there is no on the development of dopaminergic cerebellar afferent projections.

\section{Cerebellar histaminergic afferents}

Histamine plays a role as a neurotransmitter or a neuromodulator in the cerebellum. Interestingly, there are direct fiber connections from the tuberomammillary nucleus of the hypothalamus to the cerebellum [201], suggesting that histamine is involved in signal transmission from the hypothalamus to the cerebellum [202]. It has been proposed that histaminergic fiber projections to the cerebellum are important in regulating the level of behavioral arousal, and in the control of autonomic and emotional functions $[46,199]$. Histaminergic cerebellar afferents have been shown to be present in the cerebellum of the rat, guinea pig and human [203-205].

\section{Development of cerebellar histaminergic afferents}

The first histamine-immunoreactive neurons have been demonstrated at E13 in the border of the mesencephalon and metencephalon [206]. However, additional information is needed regarding further development of histaminergic cerebellar afferents.

\section{Conclusions}

The order in which cerebellar afferent projections appear throughout the development of embryonic mice and rats, in comparison with the other species, has shown that there is a general pattern in the arrival of cerebellar afferents during embryonic development. This suggests that the appearance of early cerebellar afferents takes place during a short period; those from the vestibular nuclei, inferior olive, trigeminal, and reticular nuclei arrive first, followed by the connections from spinal cord. Knowing the order in which cerebellar afferents arrive will provide information about the role that afferents may play during early embryonic development of the cerebellar primordium. The earliest afferent projections to the cerebellum may be involved in development, acting as a scaffold for subsequent incoming afferents, thereby establishing cerebellar circuitry and function. Limited knowledge about the order of cerebellar afferent development during the embryonic period prevents appropriate conclusions from being made, and requires further experimentation in this area. There is no developmental information available regarding some cerebellar afferents, particularly in the neuromodulatory category. Thus, further research is required to close this knowledge gap. In addition, because less sensitive methods were used in the past we suggest that the study of cerebellar afferent fiber development should be revisited by utilizing genetically encoded tools to detect the sequence of afferent projections during developing.

\section{Competing interests}

The authors declare that they have no competing interests.

\section{Authors' contributions}

$M R B$ and $H M$ participated in preparing mossy fiber section, $K B, M B$, and $H M$ participated in climbing fiber preparation, PA, MB and HM contributed in preparing neuromodulatory afferents, and BY and $\mathrm{HM}$ are coordinated in editing the draft of the manuscript, designed by HM. All authors read and approved the final manuscript.

\section{Acknowledgement}

The authors gratefully acknowledge the financial support of the Natural Sciences and Engineering Research Council of Canada (NSERC Discovery Grant 341921-2012) and a FHS Bridge Funding of Highly Ranked CIHR Open Operating Grants to HM.

\section{Author details}

${ }^{1}$ Department of Human Anatomy and Cell Science, College of Medicine, Faculty of Health Sciences, University of Manitoba, Rm129, BMSB, 745 Bannatyne Avenue, Winnipeg, Manitoba R3E 0J9, Canada. ${ }^{2}$ College of Medicine, Faculty of Health Sciences, Manitoba Institute of Child Health $(\mathrm{MICH})$, University of Manitoba, Winnipeg, Manitoba, Canada. ${ }^{3}$ Program in Physiology and Experimental Medicine, Hospital for Sick Children and University of Toronto, Toronto, Ontario, Canada.

Received: 17 March 2015 Accepted: 19 May 2015

Published online: 11 June 2015

\section{References}

1. Ito M. The modifiable neuronal network of the cerebellum. Jpn J Physiol. 1984;34:781-92.

2. Ito M. Control of mental activities by internal models in the cerebellum. Nat Rev Neurosci. 2008;9:304-13. doi:10.1038/nrn2332.

3. Leiner $\mathrm{HC}$, Leiner $\mathrm{AL}$, Dow RS. Does the cerebellum contribute to mental skills? Behav Neurosci. 1986;100:443-54.

4. Schmahmann JD. From movement to thought: anatomic substrates of the cerebellar contribution to cognitive processing. Hum Brain Mapp. 1996:4:174-98.

5. Reeber SL, Otis TS, Sillitoe RV. New roles for the cerebellum in health and disease. Front Syst Neurosci. 2013;7:83. doi:10.3389/fnsys.2013.00083.

6. Voogd J. The morphology of the cerebellum the last 25 years. Eur J Morphol. 1992;30:81-96.

7. Sotelo C, Wassef M. Cerebellar development: afferent organization and Purkinje cell heterogeneity. Philos Trans R Soc Lond B Biol Sci. 1991;331:307-13. doi10.1098/rstb.1991.0022.

8. Larsell $\mathrm{O}$, Jansen J. The Comparative Anatomy and Histology of the Cerebellum. The Human Cerebellum, Cerebellar Connection, and Cerebellar Cortex. Archiveth ed. Minnesota: University of Minnesota Press; 1972.

9. Marzban H, Kim CT, Doorn D, Chung SH, Hawkes R. A novel transverse expression domain in the mouse cerebellum revealed by a 
neurofilament-associated antigen. Neuroscience. 2008;153:1190-201. doi:10.1016/j.neuroscience.2008.02.036.

10. Sawada K, Fukui Y, Hawkes R. Spatial distribution of corticotropin-releasing factor immunopositive climbing fibers in the mouse cerebellum: analysis by whole mount immunohistochemistry. Brain Res. 2008;1222:106-17. doi:10.1016/j.brainres.2008.05.029.

11. Ozol K, Hayden JM, Oberdick J, Hawkes R. Transverse zones in the vermis of the mouse cerebellum. J Comp Neurol. 1999:412:95-111.

12. Armstrong CL, Krueger-Naug AM, Currie RW, Hawkes R. Constitutive expression of the $25-\mathrm{kDa}$ heat shock protein Hsp25 reveals novel parasagittal bands of purkinje cells in the adult mouse cerebellar cortex. J Comp Neurol. 2000;416:383-97.

13. Akintunde A, Eisenman LM. External cuneocerebellar projection and Purkinje cell zebrin II bands: a direct comparison of parasagittal banding in the mouse cerebellum. J Chem Neuroanat. 1994;7:75-86.

14. Ji Z, Hawkes R. Topography of Purkinje cell compartments and mossy fiber terminal fields in lobules II and III of the rat cerebellar cortex: spinocerebellar and cuneocerebellar projections. Neuroscience. 1994;61:935-54.

15. Sugihara I. Organization and remodeling of the olivocerebellar climbing fiber projection. Cerebellum. 2006;5:15-22. doi:10.1080/14734220500527385.

16. Sugihara I, Shinoda Y. Molecular, topographic, and functional organization of the cerebellar cortex: a study with combined aldolase $\mathrm{C}$ and olivocerebellar labeling. J Neurosci. 2004;24:8771-85. doi:10.1523/ JNEUROSCI.1961-04.2004

17. Bailey K, Rahimi Balaei M, Mannan A, Del Bigio MR, Marzban H. Purkinje cell compartmentation in the cerebellum of the lysosomal Acid phosphatase 2 mutant mouse (nax - naked-ataxia mutant mouse). PLoS One. 2014;9:e94327. doi:10.1371/journal.pone.0094327.

18. Bailey K, Rahimi Balaei M, Mehdizadeh M, Marzban H. Spatial and temporal expression of lysosomal acid phosphatase 2 (ACP2) reveals dynamic patterning of the mouse cerebellar cortex. Cerebellum. 2013;12:870-81. doi:10.1007/s12311-013-0502-y.

19. Voogd J, Gerrits NM, Ruigrok TJ. Organization of the vestibulocerebellum. Ann N Y Acad Sci. 1996;781:553-79.

20. Chung SH, Marzban H, Watanabe M, Hawkes R. Phospholipase Cbeta4 expression identifies a novel subset of unipolar brush cells in the adult mouse cerebellum. Cerebellum. 2009;8:267-76. doi:10.1007/s12311-009-0092-x.

21. Baumel Y, Jacobson GA, Cohen D. Implications of functional anatomy on information processing in the deep cerebellar nuclei. Front Cell Neurosci. 2009;3:14. doi:10.3389/neuro.03.014.2009.

22. Manto M, Schmahmann JD, Rossi F, Gruol DL, Koibuchi N. Handbook of the Cerebellum and Cerebellar Disorders. Netherlands: Springer; 2013.

23. Marani E, Voogd J. The morphology of the mouse cerebellum. Acta Morphol Neerl Scand. 1979;17:33-52.

24. Voogd J. The human cerebellum. J Chem Neuroanat. 2003;26:243-52.

25. Yaginuma H, Matsushita M. Spinocerebellar projections from the upper lumbar segments in the cat, as studied by anterograde transport of wheat germ agglutinin-horseradish peroxidase. J Comp Neurol. 1989;281:298-319 doi:10.1002/cne.902810211.

26. Marfurt CF, Rajchert DM. Trigeminal primary afferent projections to "non-trigeminal" areas of the rat central nervous system. J Comp Neurol. 1991;303:489-511. doi:10.1002/cne.903030313.

27. Steindler DA. Trigeminocerebellar, trigeminotectal, and trigeminothalamic projections: a double retrograde axonal tracing study in the mouse. J Comp Neurol. 1985;237:155-75. doi:10.1002/cne.902370203.

28. Voogd J, Epema AH, Rubertone JA. Cerebello-vestibular connections of the anterior vermis. A retrograde tracer study in different mammals including primates. Arch Ital Biol. 1991;129:3-19.

29. Epema AH, Gerrits NM, Voogd J. Secondary vestibulocerebellar projections to the flocculus and uvulo-nodular lobule of the rabbit: a study using HRP and double fluorescent tracer techniques. Exp Brain Res. 1990;80:72-82.

30. Valle MS, Garifoli A, Maci T, Perciavalle V. Reticulocerebellar projections to the anterior and posterior lobes of the rat cerebellum. Neurosci Lett. 2001;314:41-4

31. Brodal P. Demonstration of a somatotopically organized projection onto the paramedian lobule and the anterior lobe from the lateral reticular nucleus: an experimental study with the horseradish peroxidase method. Brain Res. 1975:95:221-39.

32. Gerrits NM, Voogd J. The nucleus reticularis tegmenti pontis and the adjacent rostral paramedian reticular formation: differential projections to the cerebellum and the caudal brain stem. Exp Brain Res. 1986;62:29-45.
33. Brodal P. Further observations on the cerebellar projections from the pontine nuclei and the nucleus reticularis tegmenti pontis in the rhesus monkey. J Comp Neurol. 1982;204:44-55. doi:10.1002/cne.902040106.

34. Serapide MF, Cicirata F, Sotelo C, Panto MR, Parenti R. The pontocerebellar projection: longitudinal zonal distribution of fibers from discrete regions of the pontine nuclei to vermal and parafloccular cortices in the rat. Brain Res. 1994;644:175-80.

35. Azizi SA, Mihailoff GA, Burne RA, Woodward DJ. The pontocerebellar system in the rat: an HRP study. I Posterior vermis. J Comp Neurol. 1981;197:543-8. doi:10.1002/cne.901970402.

36. Glickstein M, Gerrits N, Kralj-Hans I, Mercier B, Stein J, Voogd J. Visual pontocerebellar projections in the macaque. J Comp Neurol. 1994;349:51-72. doi:10.1002/cne.903490105.

37. Belknap DB, McCrea RA. Anatomical connections of the prepositus and abducens nuclei in the squirrel monkey. J Comp Neurol. 1988;268:13-28. doi:10.1002/cne.902680103.

38. Gravel C, Hawkes R. Parasagittal organization of the rat cerebellar cortex: direct comparison of Purkinje cell compartments and the organization of the spinocerebellar projection. J Comp Neurol. 1990;291:79-102. doi:10.1002/cne.902910107.

39. Wu HS, Sugihara I, Shinoda Y. Projection patterns of single mossy fibers originating from the lateral reticular nucleus in the rat cerebellar cortex and nuclei. J Comp Neurol. 1999:411:97-118.

40. Serapide MF, Panto MR, Parenti R, Zappala A, Cicirata F. Multiple zonal projections of the basilar pontine nuclei to the cerebellar cortex of the rat. J Comp Neurol. 2001;430:471-84.

41. Desclin JC. Histological evidence supporting the inferior olive as the major source of cerebellar climbing fibers in the rat. Brain Res. 1974;77:365-84.

42. Sugihara I, Wu H, Shinoda Y. Morphology of axon collaterals of single climbing fibers in the deep cerebellar nuclei of the rat. Neurosci Lett. 1996;217:33-6.

43. Eisenman LM. Organization of the olivocerebellar projection to the uvula in the rat. Brain Behav Evol. 1984;24:1-12.

44. Eisenman LM. Olivocerebellar projections to the pyramis and copula pyramidis in the rat: differential projections to parasagittal zones. J Comp Neurol. 1981;199:65-76. doi:10.1002/cne.901990105.

45. Campbell NC, Armstrong DM. Topographical localization in the olivocerebellar projection in the rat: an autoradiographic study. Brain Res. 1983;275:235-49.

46. Schweighofer N, Doya K, Kuroda S. Cerebellar aminergic neuromodulation: towards a functional understanding. Brain Res Brain Res Rev. 2004;44:103-16. doi:10.1016/j.brainresrev.2003.10.004.

47. Ito M. Long-term depression. Annu Rev Neurosci. 1989;12:85-102. doi:10.1146/annurev.ne.12.030189.000505.

48. Jaarsma D, Ruigrok TJ, Caffe R, Cozzari C, Levey Al, Mugnaini E, et al. Cholinergic innervation and receptors in the cerebellum. Prog Brain Res. 1997;114:67-96.

49. Jueptner M, Ottinger S, Fellows SJ, Adamschewski J, Flerich L, Muller SP, et al. The relevance of sensory input for the cerebellar control of movements. Neuroimage. 1997:5:41-8. doi:10.1006/nimg.1996.0249.

50. Chilton JK. Molecular mechanisms of axon guidance. Dev Biol. 2006;292:13-24. doi:10.1016/j.ydbio.2005.12.048.

51. Weth F, Fiederling F, Gebhardt C, Bastmeyer M. Chemoaffinity in topographic mapping revisited - Is it more about fiber-fiber than fiber-target interactions? Semin Cell Dev Biol. 2014. doi:10.1016/ j.semcdb.2014.07.010.

52. Hou ST, Jiang SX, Smith RA. Permissive and repulsive cues and signalling pathways of axonal outgrowth and regeneration. Int Rev Cell Mol Biol. 2008:267:125-81. doi:10.1016/S1937-6448(08)00603-5.

53. Pasterkamp RJ. Getting neural circuits into shape with semaphorins. Nat Rev Neurosci. 2012;13:605-18. doi:10.1038/nrn3302.

54. Rajasekharan S, Kennedy TE. The netrin protein family. Genome Biol. 2009;10:239. doi:10.1186/gb-2009-10-9-239.

55. Masuda T, Sakuma C, Yaginuma H. Role for netrin-1 in sensory axonal guidance in higher vertebrates. Fukushima J Med Sci. 2009:55:1-6.

56. Liao WX, Wing DA, Geng JG, Chen DB. Perspectives of SLIT/ROBO signaling in placental angiogenesis. Histol Histopathol. 2010;25:1181-90.

57. Li XT, Zhou QS, Yu Q, Zhao X, Liu QX. Current progress in functions of axon guidance molecule Robo and underlying molecular mechanism. Sheng Li Xue Bao. 2014;66:373-85. 
58. Lilienbaum A, Reszka AA, Horwitz AF, Holt CE. Chimeric integrins expressed in retinal ganglion cells impair process outgrowth in vivo. Mol Cell Neurosci. 1995;6:139-52. doi:10.1006/mcne.1995.1013.

59. Bonkowsky JL, Yoshikawa S, O'Keefe DD, Scully AL, Thomas JB. Axon routing across the midline controlled by the Drosophila Derailed receptor. Nature. 1999;402:540-4. doi:10.1038/990122.

60. Charron F, Stein E, Jeong J, McMahon AP, Tessier-Lavigne M. The morphogen sonic hedgehog is an axonal chemoattractant that collaborates with netrin-1 in midline axon guidance. Cell. 2003;113:11-23.

61. Bourikas D, Pekarik V, Baeriswyl T, Grunditz A, Sadhu R, Nardo M, et al. Sonic hedgehog guides commissural axons along the longitudinal axis of the spinal cord. Nat Neurosci. 2005:8:297-304. doi:10.1038/nn1396.

62. Augsburger A, Schuchardt A, Hoskins S, Dodd J, Butler S. BMPs as mediators of roof plate repulsion of commissural neurons. Neuron. 1999;24:127-41.

63. Nishida K, Flanagan JG, Nakamoto M. Domain-specific olivocerebellar projection regulated by the EphA-ephrin-A interaction. Development. 2002;129:5647-58.

64. Karam SD, Dottori M, Ogawa K, Henderson JT, Boyd AW, Pasquale EB, et al. EphA4 is not required for Purkinje cell compartmentation. Brain Res Dev Brain Res. 2002;135:29-38.

65. Karam SD, Burrows RC, Logan C, Koblar S, Pasquale EB, Bothwell M. Eph receptors and ephrins in the developing chick cerebellum: relationship to sagittal patterning and granule cell migration. J Neurosci. 2000;20:6488-500

66. Baader SL, Vogel MW, Sanlioglu S, Zhang X, Oberdick J. Selective disruption of "late onset" sagittal banding patterns by ectopic expression of engrailed- 2 in cerebellar Purkinje cells. J Neurosci. 1999;19:5370-9.

67. Sillitoe RV, Joyner AL. Morphology, molecular codes, and circuitry produce the three-dimensional complexity of the cerebellum. Annu Rev Cell Dev Biol. 2007;23:549-77. doi:10.1146/annurev.cellbio.23.090506.123237.

68. Ackerman SL, Kozak LP, Przyborski SA, Rund LA, Boyer BB, Knowles BB. The mouse rostral cerebellar malformation gene encodes an UNC-5-like protein. Nature. 1997;386:838-42. doi:10.1038/386838a0

69. Hall AC, Lucas FR, Salinas PC. Axonal remodeling and synaptic differentiation in the cerebellum is regulated by WNT-7a signaling. Cell. 2000;100:525-35.

70. Dun XP. Origin of climbing fiber neurons and the definition of rhombic lip. Int J Dev Neurosci. 2012;30:391-5. doi:10.1016/j.ijdevneu.2012.02.002.

71. McEvilly RJ, Erkman L, Luo L, Sawchenko PE, Ryan AF, Rosenfeld MG. Requirement for Brn-3.0 in differentiation and survival of sensory and motor neurons. Nature. 1996;384:574-7. doi:10.1038/384574a0.

72. Bae YK, Kani S, Shimizu T, Tanabe K, Nojima H, Kimura Y, et al. Anatomy of zebrafish cerebellum and screen for mutations affecting its development. Dev Biol. 2009;330:406-26. doi:10.1016/j.ydbio.2009.04.013.

73. Sherrard RM, Bower AJ. Climbing fiber development: do neurotrophins have a part to play? Cerebellum. 2002;1:265-75. doi:10.1080/147342202320883579.

74. Hawkes R. Purkinje cell stripes and long-term depression at the paralle fiber-Purkinje cell synapse. Front Syst Neurosci. 2014;8:41. doi:10.3389/ fnsys.2014.00041.

75. Grishkat HL, Eisenman LM. Development of the spinocerebellar projection in the prenatal mouse. J Comp Neurol. 1995;363:93-108. doi:10.1002/cne.903630109.

76. Delgado-Garcia JM. Structure and function of the cerebellum. Rev Neurol. 2001;33:635-42.

77. Mason CA, Gregory E. Postnatal maturation of cerebellar mossy and climbing fibers: transient expression of dual features on single axons. $J$ Neurosci. 1984;4:1715-35.

78. Kalinovsky A, Boukhtouche F, Blazeski R, Bornmann C, Suzuki N, Mason CA, et al. Development of axon-target specificity of ponto-cerebellar afferents. PLoS Biol. 2011;9, e1001013. doi:10.1371/journal.pbio.1001013.

79. Tolbert DL, Pittman T, Alisky JM, Clark BR. Chronic NMDA receptor blockade or muscimol inhibition of cerebellar cortical neuronal activity alters the development of spinocerebellar afferent topography. Brain Res Dev Brain Res. 1994;80:268-74.

80. Arsenio Nunes ML, Sotelo C, Wehrle R. Organization of spinocerebellar projection map in three types of agranular cerebellum: Purkinje cells vs. granule cells as organizer element. J Comp Neurol. 1988;273:120-36. doi:10.1002/cne.902730110.

81. Eisenman LM, Arlinghaus LE. Spinocerebellar projection in the meander tail mutant mouse: organization in the granular posterior lobe and the agranular anterior lobe. Brain Res. 1991;558:149-52.
82. Matsushita M, Tanami T. Contralateral termination of primary afferent axons in the sacral and caudal segments of the cat, as studied by anterograde transport of horseradish peroxidase. J Comp Neurol. 1983;220:206-18. doi:10.1002/cne.902200208.

83. Matsushita M, Hosoya Y, Ikeda M. Anatomical organization of the spinocerebellar system in the cat, as studied by retrograde transport of horseradish peroxidase. J Comp Neurol. 1979;184:81-106. doi:10.1002/cne.901840106.

84. Shrestha SS, Bannatyne BA, Jankowska E, Hammar I, Nilsson E, Maxwell DJ. Excitatory inputs to four types of spinocerebellar tract neurons in the cat and the rat thoraco-lumbar spinal cord. J Physiol. 2012:590:1737-55. doi:10.1113/jphysiol.2011.226852.

85. Oscarsson O. Functional Organization of the Spino- and Cuneocerebellar Tracts. Physiol Rev. 1965;45:495-522.

86. Lundberg A. Function of the ventral spinocerebellar tract. A new hypothesis. Exp Brain Res. 1971;12:317-30.

87. Hammar I, Krutki P, Drzymala-Celichowska H, Nilsson E, Jankowska E. A trans-spinal loop between neurones in the reticular formation and in the cerebellum. J Physiol. 2011;589:653-65. doi:10.1113/jphysiol.2010.201178.

88. Necker R. Spinal neurons projecting to anterior or posterior cerebellum in the pigeon. Anat Embryol (Berl). 1992;185:325-34.

89. Manto MU. The wide spectrum of spinocerebellar ataxias (SCAs). Cerebellum. 2005;4:2-6. doi:10.1080/14734220510007914.

90. Jayadev S, Bird TD. Hereditary ataxias: overview. Genet Med. 2013;15:673-83. doi:10.1038/gim.2013.28.

91. White JJ, Sillitoe RV. Development of the cerebellum: from gene expression patterns to circuit maps. Wiley Interdiscip Rev Dev Biol. 2013;2:149-64. doi:10.1002/wdev.65.

92. Lakke EA. The projections to the spinal cord of the rat during development: a timetable of descent. Adv Anat Embryol Cell Biol. 1997;135:I-XIV, 1-143.

93. Joshua M, Medina JF, Lisberger SG. Diversity of neural responses in the brainstem during smooth pursuit eye movements constrains the circuit mechanisms of neural integration. J Neurosci. 2013;33:6633-47. doi:10.1523/ JNEUROSCI.3732-12.2013

94. Ashwell KW, Zhang LL. Ontogeny of afferents to the fetal rat cerebellum. Acta Anat (Basel). 1992;145:17-23.

95. Kim D, Ackerman SL. The UNC5C netrin receptor regulates dorsal guidance of mouse hindbrain axons. J Neurosci. 2011;31:2167-79. doi:10.1523/ JNEUROSCI.5254-10.2011.

96. Lakke EA, Guldemond JM, Voogd J. The ontogeny of the spinocerebellar projection in the chicken. A study using WGA-HRP as a tracer. Acta Histochem Suppl. 1986;32:47-51.

97. van der Linden JA, ten Donkelaar HJ. Observations on the development of cerebellar afferents in Xenopus laevis. Anat Embryol (Berl). 1987;176:431-9.

98. Joseph BS, Whitlock DG. Central projections of selected spinal dorsal roots in anuran amphibians. Anat Rec. 1968;160:279-88. doi:10.1002/ar.1091600214.

99. Antal M, Tornai I, Szekely G. Longitudinal extent of dorsal root fibres in the spinal cord and brain stem of the frog. Neuroscience. 1980;5:1311-22.

100. Bangma GC, ten Donkelaar H. Afferent connections of the cerebellum in various types of reptiles. J Comp Neurol. 1982;207:255-73. doi:10.1002/ cne.902070306.

101. Rodriguez-Moldes I, Carrera I, Pose-Mendez S, Quintana-Urzainqui I, Candal $E$, Anadon R, et al. Regionalization of the shark hindbrain: a survey of an ancestral organization. Front Neuroanat. 2011;5:16. doi:10.3389/ fnana.2011.00016.

102. Pose-Mendez S, Candal E, Adrio F, Rodriguez-Moldes I. Development of the cerebellar afferent system in the shark Scyliorhinus canicula: insights into the basal organization of precerebellar nuclei in gnathostomes. J Comp Neurol. 2014;522:131-68. doi:10.1002/cne.23393.

103. Bathla G, Hegde AN. The trigeminal nerve: an illustrated review of its imaging anatomy and pathology. Clin Radiol. 2013;68:203-13. doi:10.1016/ j.crad.2012.05.019.

104. Stainier DY, Gilbert W. The monoclonal antibody B30 recognizes a specific neuronal cell surface antigen in the developing mesencephalic trigeminal nucleus of the mouse. J Neurosci. 1989;9:2468-85.

105. Walker HK. Cranial nerve V: the trigeminal nerve. In: HK Walker, WD Hall, JW Hurst, editors. Clinical Methods: the history, physical, and laboratory examinations. Boston; 1990

106. Billig I, Yatim N, Compoint C, Buisseret-Delmas C, Buisseret P. Cerebellar afferences from the mesencephalic trigeminal nucleus in the rat. Neuroreport. 1995;6:2293-6. 
107. Hayashi H, Sumino R, Sessle BJ. Functional organization of trigeminal subnucleus interpolaris: nociceptive and innocuous afferent inputs, projections to thalamus, cerebellum, and spinal cord, and descending modulation from periaqueductal gray. J Neurophysiol. 1984;51:890-905.

108. Jacquin MF, Semba K, Rhoades RW, Egger MD. Trigeminal primary afferents project bilaterally to dorsal horn and ipsilaterally to cerebellum, reticular formation, and cuneate, solitary, supratrigeminal and vagal nuclei. Brain Res. 1982;246:285-91.

109. Patrick GW, Robinson MA. Collateral projections from trigeminal sensory nuclei to ventrobasal thalamus and cerebellar cortex in rats. J Morphol. 1987;192:229-36. doi:10.1002/jmor.1051920305.

110. Saigal RP, Karamanlidis AN, Voogd J, Mangana O, Michaloudi $\mathrm{H}$. Secondary trigeminocerebellar projections in sheep studied with the horseradish peroxidase tracing method. J Comp Neurol. 1980;189:537-53. doi:10.1002/cne.901890307.

111. Falls WM, Alban MM. Morphological features of identified trigeminocerebellar projection neurons in the border zone of rat trigeminal nucleus oralis. Somatosens Res. 1986:4:1-12.

112. Shambes GM, Gibson JM, Welker W. Fractured somatotopy in granule cell tactile areas of rat cerebellar hemispheres revealed by micromapping. Brain Behav Evol. 1978;15:94-140.

113. Patrick GW, Haines DE. Cerebellar afferents to paramedian lobule from the trigeminal complex in Tupaia glis: a horseradish peroxidase (HRP) study. J Morphol. 1982;172:209-22. doi:10.1002/jmor.1051720207.

114. Gonzalez A, ten Donkelaar HJ, de Boer-van Huizen R. Cerebellar connections in Xenopus laevis. An HRP study. Anat Embryol (Berl). 1984;169:167-76.

115. Arends JJ, Dubbeldam JL. The subnuclei and primary afferents of the descending trigeminal system in the mallard (Anas platyrhynchos L.). Neuroscience. 1984;13:781-95.

116. Gould BB. Organization of afferents from the brain stem nuclei to the cerebellar cortex in the cat. Adv Anat Embryol Cell Biol. 1980;62:v-viii, 1-90.

117. Arends JJ, Woelders-Blok A, Dubbeldam JL. The efferent connections of the nuclei of the descending trigeminal tract in the mallard (Anas platyrhynchos L.). Neuroscience. 1984;13:797-817.

118. Altman J, Bayer SA. Development of the brain stem in the rat. II. Thymidine-radiographic study of the time of origin of neurons of the upper medulla, excluding the vestibular and auditory nuclei. J Comp Neurol. 1980;194:37-56. doi:10.1002/cne.901940103.

119. Barmack NH. Central vestibular system: vestibular nuclei and posterior cerebellum. Brain Res Bull. 2003;60:511-41.

120. Highstein SM, Holstein GR. The anatomy of the vestibular nuclei. Prog Brain Res. 2006:151:157-203. doi:10.1016/S0079-6123(05)51006-9.

121. Langer T, Fuchs AF, Scudder CA, Chubb MC. Afferents to the flocculus of the cerebellum in the rhesus macaque as revealed by retrograde transport of horseradish peroxidase. J Comp Neurol. 1985;235:1-25. doi:10.1002/cne.902350102.

122. Matsushita M, Wang CL. Projection pattern of vestibulocerebellar fibers in the anterior vermis of the cat: an anterograde wheat germ agglutinin-horseradish peroxidase study. Neurosci Lett. 1987;74:25-30.

123. Gerrits NM, Epema AH, van Linge A, Dalm E. The primary vestibulocerebellar projection in the rabbit: absence of primary afferents in the flocculus. Neurosci Lett. 1989;105:27-33.

124. Malinvaud D, Vassias I, Reichenberger I, Rossert C, Straka H. Functional organization of vestibular commissural connections in frog. J Neurosci. 2010:30:3310-25. doi:10.1523/JNEUROSCI.5318-09.2010.

125. Llinas R, Precht W, Kitai ST. Cerebellar Purkinje cell projection to the peripheral vestibular organ in the frog. Science. 1967;158:1328-30.

126. Fuller PM. Projections of the vestibular nuclear complex in the bullfrog (Rana catesbeiana). Brain Behav Evol. 1974;10:157-69.

127. Schwarz IE, Schwarz DW. Afferents to the cerebellar cortex of turtles studied by means of the horseradish peroxidase technique. Anat Embryol (Berl). 1980;160:39-52.

128. Brecha N, Karten HJ, Hunt SP. Projections of the nucleus of the basal optic root in the pigeon: an autoradiographic and horseradish peroxidase study. J Comp Neurol. 1980;189:615-70. doi:10.1002/cne.901890404.

129. Kotchabhakdi N, Walberg F. Primary vestibular afferent projections to the cerebellum as demonstrated by retrograde axonal transport of horseradish peroxidase. Brain Res. 1978;142:142-6.

130. Korte GE, Mugnaini E. The cerebellar projection of the vestibular nerve in the cat. J Comp Neurol. 1979;184:265-77. doi:10.1002/cne.901840204.
131. Ruben RJ. Development of the inner ear of the mouse: a radioautographic study of terminal mitoses. Acta Otolaryngol. 1967; Suppl 220:1-44.

132. Altman J, Bayer SA. Development of the brain stem in the rat. III. Thymidine-radiographic study of the time of origin of neurons of the vestibular and auditory nuclei of the upper medulla. J Comp Neurol. 1980;194:877-904. doi:10.1002/cne.901940410.

133. Maklad A, Kamel S, Wong E, Fritzsch B. Development and organization of polarity-specific segregation of primary vestibular afferent fibers in mice. Cell Tissue Res. 2010;340:303-21. doi:10.1007/s00441-010-0944-1.

134. Morris RJ, Beech JN, Heizmann CW. Two distinct phases and mechanisms of axonal growth shown by primary vestibular fibres in the brain, demonstrated by parvalbumin immunohistochemistry. Neuroscience. 1988;27:571-96.

135. McConnell JA, Sechrist JW. Identification of early neurons in the brainstem and spinal cord: I. An autoradiographic study in the chick. J Comp Neurol. 1980;192:769-83. doi:10.1002/cne.901920410.

136. Gray's Anatomy, The Anatomical Basis of Clinical Practice. Churchill Livingstone; 2008.

137. Clendenin M, Ekerot CF, Oscarsson O, Rosen I. Distribution in cerebellar cortex of mossy fibre afferents from the lateral reticular nucleus in the cat. Brain Res. 1974;69:136-9.

138. Ghazi H, Hrycyshyn AW, Flumerfelt BA. Double-labeling study of axonal branching within the lateral reticulocerebellar projection in the rat. J Comp Neurol. 1987;258:378-86. doi:10.1002/cne.902580306.

139. Altman J, Bayer SA. Development of the precerebellar nuclei in the rat: III. The posterior precerebellar extramural migratory stream and the lateral reticular and external cuneate nuclei. J Comp Neurol. 1987;257:513-28. doi:10.1002/cne.902570404.

140. Brodal P, Bjaalie JG. Organization of the pontine nuclei. Neurosci Res. 1992;13:83-118.

141. Odeh F, Ackerley R, Bjaalie JG, Apps R. Pontine maps linking somatosensory and cerebellar cortices are in register with climbing fiber somatotopy. J Neurosci. 2005;25:5680-90. doi:10.1523/JNEUROSCI.0558-05.2005.

142. Holtzman T, Cerminara NL, Edgley SA, Apps R. Characterization in vivo of bilaterally branching pontocerebellar mossy fibre to Golgi cell inputs in the rat cerebellum. Eur J Neurosci. 2009;29:328-39. doi:10.1111/j.14609568.2008.06572.x.

143. Gerrits NM, Voogd J. The projection of the nucleus reticularis tegmenti pontis and adjacent regions of the pontine nuclei to the central cerebellar nuclei in the cat. J Comp Neurol. 1987;258:52-69. doi:10.1002/ cne.902580104.

144. Leergaard TB, Bjaalie JG. Topography of the complete corticopontine projection: from experiments to principal Maps. Front Neurosci. 2007;1:211-23. doi:10.3389/neuro.01.1.1.016.2007.

145. Yee KT, Simon HH, Tessier-Lavigne M, O'Leary DM. Extension of long leading processes and neuronal migration in the mammalian brain directed by the chemoattractant netrin-1. Neuron. 1999;24:607-22.

146. Altman J, Bayer SA. Prenatal development of the cerebellar system in the rat. II. Cytogenesis and histogenesis of the inferior olive, pontine gray, and the precerebellar reticular nuclei. J Comp Neurol. 1978;179:49-75. doi:10.1002/cne.901790105.

147. Wingate RJ, Hatten ME. The role of the rhombic lip in avian cerebellum development. Development. 1999;126:4395-404.

148. Clarke PG. Some visual and other connections to the cerebellum of the pigeon. J Comp Neurol. 1977;174:535-52. doi:10.1002/cne.901740307.

149. Sotelo C, Hillman DE, Zamora AJ, Llinas R. Climbing fiber deafferentation: its action on Purkinje cell dendritic spines. Brain Res. 1975;98:574-81.

150. Brodal A, Kawamura K. Olivocerebellar projection: a review. Adv Anat Embryol Cell Biol. 1980;64:IVIII, 1-140.

151. Sotelo C. Cellular and genetic regulation of the development of the cerebellar system. Prog Neurobiol. 2004;72:295-339. doi:10.1016/ j.pneurobio.2004.03.004.

152. Azizi SA, Woodward DJ. Inferior olivary nuclear complex of the rat: morphology and comments on the principles of organization within the olivocerebellar system. J Comp Neurol. 1987;263:467-84. doi:10.1002/ cne.902630402.

153. Ito M, Kano M. Long-lasting depression of parallel fiber-Purkinje cell transmission induced by conjunctive stimulation of parallel fibers and climbing fibers in the cerebellar cortex. Neurosci Lett. 1982;33:253-8.

154. Llinas R. Eighteenth Bowditch lecture. Motor aspects of cerebellar control. Physiologist. 1974;17:19-46. 
155. Cochran SL, Hackett JT. The climbing fiber afferent system of the frog. Brain Res. 1977;121:362-7.

156. Cochran SL, Hackett JT. Phylogenetically consistent features of cerebellar climbing fibers present in the tadpole. Brain Res. 1980;192:543-9.

157. Freedman SL, Voogd J, Vielvoye GJ. Experimental evidence for climbing fibers in the avian cerebellum. J Comp Neurol. 1977;175:243-52. doi:10.1002/cne.901750207.

158. Barnes JA, Ebner BA, Duvick LA, Gao W, Chen G, Orr HT, et al. Abnormalities in the climbing fiber-Purkinje cell circuitry contribute to neuronal dysfunction in ATXN1[82Q] mice. J Neurosci. 2011;31:12778-89. doi:10.1523/JNEUROSCI.2579-11.2011.

159. Hidalgo-Sanchez M, Backer S, Puelles L, Bloch-Gallego E. Origin and plasticity of the subdivisions of the inferior olivary complex. Dev Biol. 2012;371:215-26. doi:10.1016/j.ydbio.2012.08.019.

160. Bourrat F, Sotelo C. Migratory pathways and neuritic differentiation of inferior olivary neurons in the rat embryo. Axonal tracing study using the in vitro slab technique. Brain Res. 1988:467:19-37.

161. Armstrong RC, Clarke PG. Neuronal death and the development of the pontine nuclei and inferior olive in the chick. Neuroscience. 1979;4:1635-47.

162. Wassef M, Cholley B, Heizmann CW, Sotelo C. Development of the olivocerebellar projection in the rat: II. Matching of the developmental compartmentations of the cerebellum and inferior olive through the projection map. J Comp Neurol. 1992;323:537-50. doi:10.1002/cne.903230406

163. Paradies MA, Eisenman LM. Evidence of early topographic organization in the embryonic olivocerebellar projection: a model system for the study of pattern formation processes in the central nervous system. Dev Dyn. 1993;197:125-45. doi:10.1002/aja.1001970206.

164. Chedotal A, Sotelo C. Early Development of Olivocerebellar Projections in the Fetal Rat Using CGRP Immunocytochemistry. Eur J Neurosci. 1992:4:1159-79.

165. Chedotal A, Pourquie O, Ezan F, San Clemente H, Sotelo C. BEN as a presumptive target recognition molecule during the development of the olivocerebellar system. J Neurosci. 1996;16:3296-310.

166. Mason CA, Christakos S, Catalano SM. Early climbing fiber interactions with Purkinje cells in the postnatal mouse cerebellum. J Comp Neurol. 1990;297:77-90. doi:10.1002/cne.902970106.

167. Morara S, van der Want JJ, de Weerd H, Provini L, Rosina A. Ultrastructural analysis of climbing fiber-Purkinje cell synaptogenesis in the rat cerebellum. Neuroscience. 2001;108:655-71.

168. Crepel F, Delhaye-Bouchaud N, Dupont JL. Fate of the multiple innervation of cerebellar Purkinje cells by climbing fibers in immature control, $x$-irradiated and hypothyroid rats. Brain Res. 1981;227:59-71.

169. Mariani J, Changeux JP. Ontogenesis of olivocerebellar relationships. I. Studies by intracellular recordings of the multiple innervation of Purkinje cells by climbing fibers in the developing rat cerebellum. J Neurosci. 1981:1:696-702.

170. Watanabe M, Kano M. Climbing fiber synapse elimination in cerebellar Purkinje cells. Eur J Neurosci. 2011;34:1697-710. doi:10.1111/j.1460-9568.2011.07894x

171. Van der Want JJ, Wiklund L, Guegan M, Ruigrok T, Voogd J. Anterograde tracing of the rat olivocerebellar system with Phaseolus vulgaris leucoagglutinin (PHA-L). Demonstration of climbing fiber collateral innervation of the cerebellar nuclei. J Comp Neurol. 1989;288:1-18. doi:10.1002/cne.902880102

172. Cummings SL, Young 3rd WS, King JS. Early development of cerebellar afferent systems that contain corticotropin-releasing factor. J Comp Neurol. 1994:350:534-49. doi:10.1002/cne.903500403.

173. Murakami Y, Uchida K, Rijli FM, Kuratani S. Evolution of the brain developmental plan: Insights from agnathans. Dev Biol. 2005;280:249-59. doi:10.1016/j.ydbio.2005.02.008.

174. Bozhilova-Pastirova A, Ovtscharoff W. The inferior oilvary complex. Adv Anat Embryol Cell Biol. 2000;155:III-VI, 1-84

175. Pose Méndez SM. Developmental study of the cerebellum in cartilaginous fishes: towards the identification of primitive features of the cerebellar formation in gnathostomes. 2013

176. Bishop GA, Ho RH. The distribution and origin of serotonin immunoreactivity in the rat cerebellum. Brain Res. 1985;331:195-207.

177. Kerr CW, Bishop GA. Topographical organization in the origin of serotoninergic projections to different regions of the cat cerebellar cortex. J Comp Neurol. 1991;304:502-15. doi:10.1002/cne.903040313.

178. Kitzman PH, Bishop GA. The origin of serotoninergic afferents to the cat's cerebellar nuclei. J Comp Neurol. 1994;340:541-50. doi:10.1002/ cne. 903400407.
179. Strahlendorf JC, Hubbard GD. Serotonergic interactions with rat cerebellar Purkinje cells. Brain Res Bull. 1983;11:265-9.

180. Saitow F, Murano M, Suzuki H. Modulatory effects of serotonin on GABAergic synaptic transmission and membrane properties in the deep cerebellar nuclei. J Neurophysiol. 2009;101:1361-74. doi:10.1152/jn.90750.2008.

181. Oades RD. Dopamine-serotonin interactions in attention-deficit hyperactivity disorder (ADHD). Prog Brain Res. 2008;172:543-65. doi:10.1016/S0079-6123(08)00926-6.

182. Ciesielski KT, Harris RJ, Hart BL, Pabst HF. Cerebellar hypoplasia and frontal lobe cognitive deficits in disorders of early childhood. Neuropsychologia. 1997;35:643-55.

183. Whitaker-Azmitia PM. Behavioral and cellular consequences of increasing serotonergic activity during brain development: a role in autism? Int J Dev Neurosci. 2005;23:75-83. doi:10.1016/j.ijdevneu.2004.07.022.

184. Lauder JM. Ontogeny of the serotonergic system in the rat: serotonin as a developmental signal. Ann N Y Acad Sci. 1990;600:297-313. discussion 4

185. Lidov HG, Molliver ME. An immunohistochemical study of serotonin neuron development in the rat: ascending pathways and terminal fields. Brain Res Bull. 1982:8:389-430.

186. Sako H, Kojima T, Okado N. Immunohistochemical study on the development of serotoninergic neurons in the chick: I. Distribution of cell bodies and fibers in the brain. J Comp Neurol. 1986;253:61-78. doi:10.1002/cne.902530106.

187. Ueda S, Nojyo Y, Sano Y. Immunohistochemical demonstration of the serotonin neuron system in the central nervous system of the bullfrog, Rana catesbeiana. Anat Embryol (Berl). 1984;169:219-29.

188. Kimoto Y, Satoh K, Sakumoto T, Tohyama M, Shimizu N. Afferent fiber connections from the lower brain stem to the rat cerebellum by the horseradish peroxidase method combined with MAO staining, with special reference to noradrenergic neurons. J Hirnforsch. 1978;19:85-100.

189. Berridge CW, Waterhouse BD. The locus coeruleus-noradrenergic system: modulation of behavioral state and state-dependent cognitive processes. Brain Res Brain Res Rev. 2003;42:33-84.

190. Singewald N, Philippu A. Release of neurotransmitters in the locus coeruleus. Prog Neurobiol. 1998;56:237-67.

191. Bickford P. Motor learning deficits in aged rats are correlated with loss of cerebellar noradrenergic function. Brain Res. 1993;620:133-8.

192. Shi M, Hu ZL, Zheng MH, Song NN, Huang Y, Zhao G, et al. Notch-Rbpj signaling is required for the development of noradrenergic neurons in the mouse locus coeruleus. J Cell Sci. 2012;125:4320-32. doi:10.1242/jcs.102152.

193. Sievers J, Klemm HP. Locus coeruleus - cerebellum: interaction during development. Bibl Anat. 1982;56-75.

194. Barmack NH, Baughman RW, Eckenstein FP. Cholinergic innervation of the cerebellum of rat, rabbit, cat, and monkey as revealed by choline acetyltransferase activity and immunohistochemistry. J Comp Neurol. 1992;317:233-49. doi:10.1002/cne.903170303.

195. Barmack NH, Baughman RW, Eckenstein FP, Shojaku H. Secondary vestibular cholinergic projection to the cerebellum of rabbit and rat as revealed by choline acetyltransferase immunohistochemistry, retrograde and orthograde tracers. J Comp Neurol. 1992;317:250-70. doi:10.1002/cne.903170304.

196. Barmack NH, Baughman RW, Eckenstein FP. Cholinergic innervation of the cerebellum of the rat by secondary vestibular afferents. Ann N Y Acad Sci. 1992;656:566-79.

197. Mallol J, Sarraga MC, Bartolome M, Ghandour MS, Gombos G. Muscarinic receptor during postnatal development of rat cerebellum: an index of cholinergic synapse formation? J Neurochem. 1984;42:1641-9.

198. Ikai Y, Takada M, Shinonaga Y, Mizuno N. Dopaminergic and non-dopaminergic neurons in the ventral tegmental area of the rat project, respectively, to the cerebellar cortex and deep cerebellar nuclei. Neuroscience. 1992:51:719-28.

199. Barili P, Bronzetti E, Ricci A, Zaccheo D, Amenta F. Microanatomical localization of dopamine receptor protein immunoreactivity in the rat cerebellar cortex. Brain Res. 2000;854:130-8.

200. Lauder JM, Bloom FE. Ontogeny of monoamine neurons in the locus coeruleus, Raphe nuclei and substantia nigra of the rat. I Cell differentiation. J Comp Neurol. 1974;155:469-81. doi:10.1002/cne.901550407.

201. Lumsden A, Krumlauf R. Patterning the vertebrate neuraxis. Science. 1996:274:1109-15.

202. Panula P, Takagi H, Inagaki N, Yamatodani A, Tohyama M, Wada H, et al. Histamine-containing nerve fibers innervate human cerebellum. Neurosc Lett. 1993;160:53-6. 
203. Takemura M, Kitanaka N, Kitanaka J. Signal transduction by histamine in the cerebellum and its modulation by $\mathrm{N}$-methyltransferase. Cerebellum. 2003;2:39-43. doi:10.1080/14734220310015601.

204. Airaksinen MS, Panula P. The histaminergic system in the guinea pig central nervous system: an immunocytochemical mapping study using an antiserum against histamine. J Comp Neurol. 1988;273:163-86. doi:10.1002/cne.902730204

205. Panula P, Airaksinen MS, Pirvola U, Kotilainen E. A histamine-containing neuronal system in human brain. Neuroscience. 1990:34:127-32.

206. Auvinen S, Panula P. Development of histamine-immunoreactive neurons in the rat brain. J Comp Neurol. 1988;276:289-303. doi:10.1002/cne.902760211.

\section{Submit your next manuscript to BioMed Central} and take full advantage of:

- Convenient online submission

- Thorough peer review

- No space constraints or color figure charges

- Immediate publication on acceptance

- Inclusion in PubMed, CAS, Scopus and Google Scholar

- Research which is freely available for redistribution 